The Cambridge Law Journal

http://journals.cambridge.org/CLJ

Additional services for The Cambridge Law Journal:

Email alerts: $\underline{\text { Click here }}$

Subscriptions: Click here

Commercial reprints: Click here

Terms of use : $\underline{\text { Click here }}$

\title{
The Constitution of the United Kingdom
}

Rodney Brazier

The Cambridge Law Journal / Volume 58 / Issue 01 / March 1999, pp 96 - 128

DOI: null, Published online: 08 September 2000

Link to this article: http://journals.cambridge.org/abstract_S0008197399001063

How to cite this article:

Rodney Brazier (1999). The Constitution of the United Kingdom. The Cambridge Law Journal, 58, pp 96-128

Request Permissions : $\underline{\text { Click here }}$ 


\title{
THE CONSTITUTION OF THE UNITED KINGDOM
}

\author{
RODNEY BRAZIER*
}

\section{First Thoughts}

THE Labour Government's diffusion of power both to new institutions and to citizens is designed to alter old constitutional settlements within the United Kingdom. By the end of this last Parliament of the twentieth century the British constitution will have been reshaped. The volume and detail of the legislation that is being brought forward to achieve this cannot be analysed adequately in one article. I intend, therefore, to concentrate here on the redrawing of legislative and executive authority between the component parts of the United Kingdom. Even doing that will require some selectivity. We need to see what will be the nature of the United Kingdom as a constitutional concept when those re-arrangements are in place. An appreciation is required of the limits on the powers that are being ceded-especially in relation to Scotland, which was once an independent state and where many aspire to independence. The union between Northern Ireland and Great Britain may be less stable under the new legislation. An understanding will be sought of the nature of the new legislative processes and ministerial authorities that are being set up in Edinburgh, Cardiff and Belfast, including the effects which arrangements for new governments in those capitals may have on the organisation of the British Government. And preliminary assessments are needed of the constitutional future of the United Kingdom itself once the new constitutional legislation is in force.

\section{UNITY AND SOVEREIGNTY}

The United Kingdom of Great Britain and Northern Ireland is a unitary sovereign state. At least for the purposes of statutory interpretation the phrase "United Kingdom" means "Great Britain and Northern Ireland". The United Kingdom, with the Channel

\footnotetext{
Professor of Law, University of Manchester. This paper has the same title as, and has been influenced by, that of Sir David Williams in [1972A] C.L.J. 266, who also commented on a draft of this paper. I am most grateful to him.

${ }^{1}$ Royal and Parliamentary Titles Act 1927, s. 2(2); Interpretation Act 1978, s. 5 and Schedule 1.
} 
Islands and the Isle of Man, ${ }^{2}$ together constitute the British Islands, ${ }^{3}$ which thus form a larger geographical and constitutional concept. But to what extent will the United Kingdom still be a unitary state when the devolution of constitutional authority to Scotland, Wales and Northern Ireland has been completed? The answer to that question requires a glance backwards through several centuries of constitutional history, and then a peer ahead at the effect of the legislation which will endow those parts of the United Kingdom with greater autonomy.

\section{A. The Union}

The union between England and Wales is the oldest and most complete in the United Kingdom. ${ }^{4}$ Although Wales was annexed by Edward I in 1284, effective integration did not come about until much later with the passing of a number of English statutes, notably the Laws in Wales Act 1535. Under that Act England and Wales were declared to be united, with Welshmen and Englishmen subject to the same laws. In the following year Welsh MPs were returned to the English Parliament and the English system of local government was extended to Wales. ${ }^{5}$ So complete, indeed, was the annexation in practice that the word "England" in Acts of Parliament was later deemed to include Wales, ${ }^{6}$ a slur which was not removed until $1967 ;^{7}$ moreover, administrative and departmental devolution was to come to Wales much later than it was to Scotland. Thus it was not until 1951 that a Cabinet Minister (the Home Secretary) was given responsibilities for the principality with the title of Minister for Welsh Affairs, and only in 1964 was the separate Welsh Office with its own Secretary of State established.

The union between England and Scotland began and was completed very differently. The accession of James VI of Scotland to the throne of England in 1603 constituted a personal union of the two crowns; only when the still separate countries agreed more than a century later to coalesce was a constitutional union born. The Articles of Union, given legislative effect by the Union with Scotland Act 1706 and the Union with England Act 1707, created a United

${ }^{2}$ On which see the Report of the Commission on the Constitution, Cmnd. 5460 (1973), vol. 1, Part XI. Those self-governing dependencies will not be considered further here.

${ }^{3}$ Interpretation Act 1978, s. 5 and Schedule 1.

${ }^{4}$ For a valuable corrective to the Anglocentric view of history in this context see John Davies, A History of Wales (1993). And see J.A. Andrews, Welsh Studies in Public Law (1970), especially chapters $2,3,4$.

${ }^{5}$ See David Williams, A History of Modern Wales (1950), chapter 3; and David G.T. Williams, "Devolution: the Welsh Perspective" in Jack Beatson, Christopher Forsyth and Ivan Hare (eds.), Constitutional Reform in the United Kingdom: Practice and Principles (1998).

${ }^{6}$ Wales and Berwick-on-Tweed Act 1746.

${ }^{7}$ Welsh Language Act 1967, s. 4. See now the Welsh Language Act 1993. 
Kingdom of Great Britain, involving the merger of the Scottish and English Parliaments - the effect, incidentally, of which merger on the sovereignty of the new Parliament never being fully settled. ${ }^{8}$ Despite that union Scotland retained and nurtured her own church, legal and judicial systems, criminal and civil law, local government, and educational system. That long history of Scottish institutions, in the main unaffected by the union, must help to explain why nationalist, or at least devolutionary, sentiment has been stronger in Scotland than in Wales. A Secretary of State for Scotland was first appointed in the British Government in 1709 , a post which was, however, abolished in the year after the 1745 rebellion. In 1885 a Secretaryship for Scotland was created, and was made up to a Secretaryship of State again in $1926 .{ }^{9}$ Administrative and departmental devolution-in itself a recognition that Scotland had been a separate and effective state before 1707-was firmly rooted in Scotland long before the devolution debate caught fire in the 1960s. ${ }^{10}$ Indeed, as the Prime Minister was to write in the recent Scottish devolution White Paper, "Scotland is a proud historic nation in the United Kingdom . . .". ${ }^{11}$

Union between Ireland and England began and has continued differently again. The attempts by the Plantagenet Kings of England to subjugate Ireland met with limited success. Despite the repression under Cromwell and William III, by 1783 the British Parliament gave up the fight when it purported to relinquish jurisdiction over Ireland. From that date until the union in 1801, in Maitland's well-known phrase, ". . . Ireland was no more subject to England than was England to Ireland". ${ }^{12}$ In 1801 the Parliament of Ireland entered into union with Great Britain, ${ }^{13}$ and one hundred Irish MPs were returned to the House of Commons, along with twenty-eight Irish representative peers to the House of Lords, in the new Parliament of Great Britain and Ireland. That union survived the Government of Ireland Act $1920^{14}$ which separated South from North and which established two Parliaments, in Dublin and Belfast. ${ }^{15}$ With the

\footnotetext{
${ }^{8}$ See, e.g., MacCormick v. Lord Advocate 1953 S.C. 396, 411-413; J.D.B. Mitchell, Constitutional Law (2nd ed., 1968), pp. 69-74; T.B. Smith, "The Union of 1707 as Fundamental Law" [1957] P.L. 99; M. Upton, "Marriage Vows of the Elephant: The Constitution of 1707" (1989) 105 L.Q.R. 79; Lord Woolf, "Droit Public_English Style" [1995] P.L. 57, 69; Sir John Laws, "Law and Democracy" [1996] P.L. 72, 84-89.

${ }^{9}$ Rodney Brazier, Ministers of the Crown (1997), p. 9.

${ }^{10}$ Report of the Commission on the Constitution, vol. 2, evidence of the Scottish Office, the Lord Advocate's Department and the Crown Office; J.P. Mackintosh, The Devolution of Power (1968). On Scottish national identity as it relates to statehood see, e.g., D. Miller, On Nationality (1995), chapter 2. And see generally Linda Colley, Britons: Forging the Nation 1707-1837 (1996).

${ }^{11}$ Scotland's Parliament, Cm. 3658 (1997), p. v.

${ }^{12}$ F.W. Maitland, Constitutional History of England (1908), p. 335.

${ }_{13}$ Act of Union with Ireland 1801.

${ }^{14}$ The Government of Ireland Act 1914 had provided for an internally self-governing Ireland with its own Parliament, but it was bitterly opposed by the Protestant majority in the North, was not activated because of the outbreak of war, and never came into effect.

${ }^{15}$ Only part of the 1920 Act became operative because of the armed uprising in the South.
} 
recognition of the Irish Free State in 1922 by the British Parliament ${ }^{16}$ Northern Ireland, ${ }^{17}$ and the United Kingdom of Great Britain and Northern Ireland, came into being. The trappings of a semiindependent state with which the 1920 Act endowed Northern Ireland-a Prime Minister, Cabinet, Privy Council, a Supreme Court, and a Senate and House of Commons with executive and legislative authority over internal affairs-survived as a Protestant unionistdominated regime until disintegration set in in 1968. As a result of that climacteric the Stormont constitution was abrogated in $1973^{18}$ to be replaced by direct rule from London through a Secretary of State for Northern Ireland. The efforts which then began to find a workable constitution were marked by tragedy and occasional (but illusory) successes. ${ }^{19}$ Current hopes for a serviceable constitutional settlement rest on the multi-party agreement reached in Belfast on Good Friday, 1998 (the Good Friday agreement). ${ }^{20}$ Its consequences for the constitution of the United Kingdom will be explored later. But Northern Ireland “. . . remains part of the United Kingdom. .... ${ }^{21}$

Thus the union between the countries, nations and regions of the United Kingdom ${ }^{22}$ was originally achieved by England through treaty-making with Scotland ${ }^{23}$ and by force in Wales and in Ireland. The whole union came to rely on the consent of the majorities in the constituent parts of the United Kingdom. Through expressions of majority opinion the nature of that union is changing with the implementation of the Labour Government's devolution plans. But even when that legislation is in operation (and there is a lingering doubt whether Northern Ireland's will be $)^{24}$ the United Kingdom will

${ }^{16}$ Irish Free State (Agreement) Act 1922; see Sir Kenneth Wheare, The Constitutional Structure of the Commonwealth (1960), pp. 90-94; Brigid Hadfield, The Constitution of Northern Ireland (1989), chapter III.

${ }^{17}$ For the meaning of "Northern Ireland", see Government of Ireland Act 1920, s. 1(2), Northern Ireland Act 1998, s. 79(1) (inclusion in that definition of internal waters and territorial sea).

18 Northern Ireland Constitution Act 1973, s. 31.

${ }^{19}$ For the constitutional story of Northern Ireland down to 1972 see Claire Palley, The Evolution, Disintegration and Possible Reconstruction of the Northern Ireland Constitution (1972); and from 1968 to 1989 see Hadfield, op. cit., chapters IV-VII. For an excellent analysis of the history from 1886 to the early 1990 s see Christopher McCrudden, "Northern Ireland and the British Constitution" in Jeffrey Jowell and Dawn Oliver (eds.), The Changing Constitution (3rd ed., 1994), chapter 12 .

${ }^{20} \mathrm{Cm} .3883$ (1998). The agreement is referred to as the "Belfast Agreement" in the Northern Ireland Act 1998, s. 79(1), but it is known popularly as the Good Friday agreement.

21 Northern Ireland Act 1998, s. 1(1).

${ }^{22}$ That description of the constituent parts comes from the terms of reference of the Royal Commission on the Constitution. In popular speech Scotland is usually described as a nation, Wales as a principality, and Northern Ireland as a province, but none of those descriptions is universally accepted.

${ }^{23}$ For that reason it has been argued that the United Kingdom is a union, rather than a unitary, state: see Stein Rokkan and Derek Urwin, "Introduction: Centres and Peripheries in Europe" in Rokkan and Urwin (eds.), The Politics of Territorial Identity (1982).

${ }^{24}$ Elections to the Scottish Parliament and the Welsh Assembly will be held in 1999 (although the Parliament will not start its duties until 2000). The implementation of the Northern Ireland package depends on important non-legal developments to the satisfaction of the Secretary of State for Northern Ireland. 
still be a unitary state. The whole of that state, and all the parts that comprise it, will remain-at least ultimately-under the jurisdiction of the Parliament of the United Kingdom ${ }^{25}$ and through it of Her Majesty's Government in the United Kingdom. Local power, of course, will remain vested in traditional local authorities, and much power will be diffused to the new institutions in Scotland, Wales and Northern Ireland. But the critical constitutional point will remain that those new institutions will owe their authority and, indeed, their existence to the Parliament of the United Kingdom. It established them; ${ }^{26}$ it could, as a matter of law, amend or take away their powers at any time through ordinary legislation; ${ }^{27}$ it could, legally, abolish any of those institutions at any time. ${ }^{28}$ Executive and legislative authorities outside the British Parliament enjoy no specially-protected position in the state, secure from easy interference from the national legislature, as they would in a federal structure. ${ }^{29}$

But, as is so often the case with the British constitution, these matters are not quite as simple as the letter of the law implies. While British parliamentary sovereignty over the whole of the United Kingdom is legally absolute, obviously it is conditioned in its operation by other factors. The place of Ireland, and later of Northern Ireland, in the British state has been (and for reasons to be explained later will remain) all too clearly an unstable one. The guarantee obtained by unionists that the province would only cease to be part of the United Kingdom with the consent (originally) of the Parliament, and (subsequently and now) the people of Northern Ireland $^{30}$ would not have been necessary had Northern Ireland's manifest destiny been as a permanent and unequivocal part of the British constitutional system. The relevance and legitimacy of the pan-Irish dimension has been accepted by the British Parliament and Government since at least the conclusion of the Anglo-Irish Agreement in $1985,{ }^{31}$ and that dimension will increase in significance under the Good Friday agreement ${ }^{32}$ which will further reduce-in effect if not in English law-the exclusive authority over Northern Ireland of the United Kingdom Parliament and Government. In Scotland the Scottish National Party (SNP) has sought independence

${ }^{25}$ The formal style of that Parliament is the Parliament of the United Kingdom of Great Britain and Northern Ireland, and has been since the Royal and Parliamentary Titles Act 1927, s. 2(1).

${ }^{26}$ Notably in the last century as it did by the Municipal Corporations Act 1882.

${ }^{27}$ As was seen under the 1979 Conservative Government.

${ }^{28}$ As was done when the Greater London Council and the metropolitan county councils were abolished by the 1979 Conservative Government.

${ }^{29}$ That point will be developed in section IV.

${ }^{30}$ Ireland Act 1949, s. 1(2); Northern Ireland Constitution Act 1973, s. 1; see now the Northern Ireland Act 1998, s. 1 (which will be examined later).

${ }^{31}$ Cmnd. 9657 (1985).

${ }^{32}$ That can be seen, for example, in the proposed North-South Ministerial Council and British-Irish Council which will be set up under that agreement (see Strands Two and Three). 
for decades, and while it plans to take a full part in the Scottish Parliament this is because the party sees devolution not as an event, but as a process towards independence. For so long as the SNP continues to represent a substantial portion of opinion in Scotland, and especially before we can see how satisfactorily the devolution package will meet the claims of the Scots, it is impossible to assert that Scotland's final system of government is at hand. To Scotland, Northern Ireland and (possibly) Wales the granting of legislative and executive authority will emphasise the fact that the legal absolutism of British parliamentary sovereignty will not be as settled throughout the United Kingdom as it was once taken to be. Indeed, while orthodox legal doctrine will continue to assert that that authority could be retaken at any time, as a matter of political reality any such action might well be out of the question, and a further important limitation on parliamentary sovereignty will have slid into place. Fortunately, no one can foresee the future: it cannot be known what the juridical total of the United Kingdom will be even in a decade's time: but at least the legal consequences of the latest expression of Parliament's will as to governance in the United Kingdom can be assessed.

\section{B. Devolution and the Union ${ }^{33}$}

The Labour Government intends that the creation of the Scottish Parliament will strengthen the union between Scotland and the rest of the United Kingdom by giving practical expression to the aspirations of the Scots to run their own affairs. ${ }^{34}$ The Government believes that this will be the basis for a final constitutional settlement. It is well known, however, that the late Conservative Government vigorously opposed devolution to Scotland largely on the ground that devolution of power would mark out a slippery slope down which the United Kingdom would unavoidably slide to break-up. And it is that slope on which the SNP wishes to ride. Its task is not hopeless, for at the time of writing the party enjoys a large lead in the opinion polls over the other political parties and on that basis would be easily the largest party in the Parliament. The Government's task has been to ensure that the terms of the Scotland Act 1998 deliver an acceptable form of home rule while preserving the unitary

\footnotetext{
${ }^{33}$ See generally Beatson, Forsyth and Hare, op. cit., chapters 1-5 (Vernon Bogdanor, Robert Reed, Anthony Bradley, David Williams, Brigid Hadfield); Constitution Unit, Scotland's Parliament (1996), An Assembly for Wales (1996), Regional Government in England (1996).

${ }^{34}$ The Government's White Paper, for example, says that "The Government's aim is a fair and just settlement for Scotland within the framework of the United Kingdom. . . Scotland will remain firmly part of the United Kingdom. ... [The Scottish Parliament] will be responsible for much of the business of government in Scotland." Scotland's Parliament, p. vii. On the White Paper see Neil Walker, "Constitutional Reform in a Cold Climate" in A. Tomkins (ed.), Scottish and Welsh Self-Government: The Challenges (1998).
} 
nature of the state. The philosophy underlying the Act is to give Scotland the greatest degree of autonomy consistent with "national" matters remaining in the hands of the British Government and Parliament. To do that the Act reserves to the United Kingdom only specified matters, so that all other powers (subject to stated exceptions) are devolved. ${ }^{35}$ So, for example, the United Kingdom Parliament reserves to itself authority over such matters as the constitution, foreign and European Union affairs, and defence, while the Parliament will have legislative authority over such matters as local government, health, education, housing, economic development, transport, law and home affairs, and so on. Vast areas of Scottish life, therefore, will be subject to laws made by Scots in Edinburgh, and Westminster's writ will no longer run over them. But what constitutional and legal mechanisms will exist to preserve the sovereignty of the United Kingdom Parliament over Scotland? Even when the Scottish Parliament has been elected, when it has chosen a First Minister and Scottish Ministers, and when Scottish legislation has started to flow, the United Kingdom Parliament will still have full legislative authority over Scotland. That Parliament could-and probably would - stay clearly within the terms of the 1998 settlement. But as a matter of law and if it felt it had to it could intervene to legislate even within devolved matters, or could even abolish the Scottish Parliament and restore the status quo ante. ${ }^{36}$ That degree of sovereignty in the Parliament of the United Kingdom is ensured through a triple lock.

The first component of that lock derives from constitutional principle. The Scottish Parliament is a devolved legislature within the United Kingdom, and remains subject to the legal sovereignty of the British Parliament. ${ }^{37}$ The only authority enjoyed by the Scottish Parliament stems from an ordinary Act of the British Parliament, ${ }^{38}$ the Scotland Act 1998 (hereafter "the Scotland Act"). That which the British Parliament has conferred it could take away. To invoke the judicial aphorism that "freedom once conferred cannot be revoked" ${ }^{39}$ would not be apt, because it was uttered in the context of a sovereign legislature (the British Parliament) conferring full

${ }^{35}$ It may be remembered that the Scotland Act 1978 attempted the process the other way round, devolving only powers which were exhaustively enumerated in that Act (which as a result was a very complicated piece of legislation).

${ }^{36}$ In the absence of some unforeseeable catastrophe, abolition is unlikely, especially because the maintenance of the Parliament was accepted by the Conservative Party after the Scottish referendum, so that all the British political parties are united behind it.

${ }^{37}$ For a discussion of devolution and entrenchment see J. McFadden and W. Bain, "Strategies for the Future: A Lasting Parliament for Scotland?" in T. St.J. Bates (ed.), Devolution to Scotland: The Legal Aspects (1997).

38 "Ordinary" in the sense that it was produced without any special method of enactment.

${ }^{39}$ Ndlwana v. Hofmeyr [1937] A.D. 229, 237. For analysis see Ian Loveland, Constitutional Law: A Critical Introduction (1996), pp. 48-57. 
independence on a former colony (South Africa), with all that that entails-the grant of unfettered legislative power, recognition as a sovereign state in international law, and so on. The Scottish Parliament ${ }^{40}$ is not a Parliament of an independent state. Nor is it a legislature within a federal system: if it were, it would enjoy rights which were protected in law against encroachment by the central legislature and executive. ${ }^{41}$ Under the United States Constitution, for example, each state of the union retains those powers which collectively were not granted to the federal Government or to Congress, and even if it wanted to Congress could not assume any of those rights without a formal constitutional amendment. ${ }^{42}$ Without one the Supreme Court would strike down any such usurpatory legislation. But no such protection applies under Scotland's new "constitution", ${ }^{43}$ and the line between reserved and devolved matters could be altered at any time by the British Parliament. This could be done in order to fine-tune the devolution settlement, ${ }^{44}$ or even so as to render nugatory a piece of Scottish legislation, or even by a complete taking back of devolved authority.

The second basis for the proposition that the British Parliament retains full legislative sovereignty over Scotland flows from the way in which that Parliament decided to give authority to the new Scottish institutions. The Scotland Act is drafted as prosaically as any other statute of the British Parliament. There is, for instance, no preamble which might have asserted in appropriately uplifting language the purposes for which the new settlement had been brought forth. ${ }^{45}$ Even passages of fundamental constitutional importance are not given the prominence which it may be said that they deserve, but are tucked away in the 132-section statute, leaving it to the assiduous reader to find them. One section, redolent of the constitutional history between England and Scotland, appears as s. 37. It is included in a group of sections headed "Other provisions", yet s. 37 actually seeks to underpin the union itself, while ensuring that legislative changes are made to it. It says "The Union with Scotland Act 1706 and the Union with England Act 1707 shall have effect subject to

${ }^{40}$ It makes no difference that the legislative body is called a "Parliament": the word is obviously grander than "Assembly" or "Council", but the question is what are its powers and how secure is it, not what is it called.

41 Federalism will be considered further in section IV.

${ }^{42}$ Constitution of the United States, article X of the Bill of Rights.

43 For a general examination of the Scotland Act 1998 as a constitutional text see Rodney Brazier, "The Scotland Bill as Constitutional Legislation" [1998] Statute Law Review 12.

${ }^{44}$ Provision is made in the Scotland Act, s. 63, for the devolution of further authority by Order in Council.

${ }^{45}$ Such words appear in many constitutions, most famously at the beginning of the United States Constitution-"We the People ...." Such an explanatory note would be unusual in a British constitutional statute, but not unprecedented: see, e.g., the preambles to the Parliament Act 1911 and the Statute of Westminster 1931. 
this Act." Surely this cannot just be an explicit statement of a rule of statutory construction, because it would be otiose: for it is settled law that a later Act prevails over an earlier one and, if inconsistent, the later impliedly overrules the earlier to the extent of the inconsistency. The drafters' explanation is, however, linked to that issue. It is stated in Notes on Clauses ${ }^{46}$ that the section is included to make clear Parliament's intention that the Scotland Act 1998 will indeed take precedence over any inconsistent provisions of the Acts of Union, thus ruling out any challenge that the 1998 Act was in breach of the Acts of Union. This was done in order to rule out arguments which have been advanced (albeit unsuccessfully) in the courts in relation to other statutes which were claimed to be ineffective as in breach of those Acts. ${ }^{47}$ The union of 1707 stands, but is qualified by the 1998 Act. Similarly, the reader has to search for the major constitutional provision in the Scotland Act which preserves the ultimate legislative power of the Parliament of the United Kingdom. It appears as the final subsection in s. 28, following provisions in that section which endow the Scottish Parliament with authority to make laws and which explain the manner in which it is to do so. Section 28(7) says simply "This section does not affect the power of the Parliament of the United Kingdom to make laws for Scotland." That provision is unqualified: the sovereignty of that Parliament over Scotland, despite anything else in the Act, continues. True, s. 28(7) is not as blunt as s. 75 of the Government of Ireland Act 1920, which declared that, notwithstanding the creation of the Parliament of Northern Ireland, ". . . the supreme authority of the Parliament of the United Kingdom shall remain unaffected and undiminished over all persons, matters and things in [Northern] Ireland and every part thereof." 48 No doubt the drafters of the Scotland Act, or their ministerial masters, thought that a more restrained formulation was required: it would not do to give too much prominence to the continuing and complete British legislative power in a measure designed to confer the maximum possible authority (short of independence) to the new Scottish institutions. Devolution was, after all, a major plank in Labour's constitutional reform programme, ${ }^{49}$ and the Government is proud of its achievement in delivering it. It is only natural that Ministers wanted the Act to be presented in positive terms. But, in legal terms, s. 28(7) achieves the

\footnotetext{
${ }^{46}$ Scottish Office, January 1998.

${ }^{47}$ There is similar provision in the Northern Ireland Act 1998, s. 2: "[T]his Act shall have effect notwithstanding any other previous enactment."

${ }^{48}$ On s. 75 see Hadfield, op. cit., pp. 66-67, 80ff.

${ }^{49}$ On which see New Labour: Because Britain Deserves Better (General Election manifesto, 1997); A New Agenda for Democracy (Labour Party, 1993); Rodney Brazier, Constitutional Reform (2nd ed., 1998), chapter 3.
} 
same as s. 75. Those who want the Scottish Parliament to have the maximum power under the constituent Act may view s. 28(7) as a provision designed for use only when the British Parliament wished to give more power to the Scottish Parliament than would be apt under the technical Order in Council procedure. ${ }^{50}$ Certainly, it could be used for that purpose, to give Scotland more authority and under a fresh British statute. But any such exhaustive interpretation would be wildly optimistic. Section 28(7) is really about the continuing sovereignty of the United Kingdom Parliament: ${ }^{.1}$ it asserts that that Parliament can continue to make laws-any laws-for Scotland, ${ }^{52}$ which could include one which legislated on a devolved matter, or which even obliterated the devolution settlement. That the United Kingdom Parliament might never wish to legislate in that way is a political conclusion, not a legal or constitutional one.

Of course, there are non-legal guarantees which underpin the 1998 settlement, especially the Labour Party's clear General Election pledge to set up the Parliament, and approval of it by the people of Scotland at the referendum by a substantial margin. ${ }^{53}$ Perhaps it follows, politically, that the settlement should not be altered to the prejudice of Scotland without the approval of its Parliament, or another referendum, or both. Yet the Scotland Act is not legally entrenched, in the sense that the term is understood in constitutional law: there is no special amending formula $;{ }^{54}$ there is no mention of a further referendum for any purpose $;^{55}$ it could be amended or repealed by a British statute enacted in the ordinary way.

The third part of the mechanism that locks Scotland into the supremacy of the United Kingdom Parliament consists of the express limitations which the Scotland Act places on the power of the Scottish Parliament to legislate. The matter may be approached through questions. As a matter of law could the Scottish Parliament enlarge its own powers? Could it even pull itself up by its own bootstraps and achieve independence without the legislative consent of the Parliament of the United Kingdom? After all, the SNP has committed itself not only to holding a referendum on independence, but to pause before doing so only to alter the terms of the oath of

${ }^{50}$ Scotland Act, s. 63: statutory functions exercisable by a Minister of the Crown may be transferred to Scottish Ministers by Order in Council.

${ }^{51}$ The Government confirmed during the committee stage on the Scotland Bill that this was, indeed, intended to be the effect: see HL Deb., vol. 592, col. 797 (21 July 1998).

${ }^{52}$ Subject, as in any British legislation, to the legal limitations imposed by European Community law.

${ }^{53} 74.3 \%$ voted for a Scottish Parliament, and $25 \cdot 7 \%$ against; $63 \cdot 7 \%$ voted for tax-varying powers for that Parliament, and $36 \cdot 5 \%$ against. The turnout was $60 \cdot 4 \%$.

${ }^{54}$ Such as the requirement in the German Constitution that amendments to it must have the support of two-thirds of the members of each chamber.

${ }^{55}$ It will be seen later that the Government of Wales Act 1998 does contain limited provision for referendums. 
allegiance which is required of Members of the Scottish Parliament (MSPs) and to substitute allegiance to the people of Scotland for allegiance to Queen Elizabeth II, her heirs and successors. Lawmaking power is conferred on the Scottish Parliament by ss. 28 and 29 of the Scotland Act. So, the Parliament may make laws, to be known as Acts of the Scottish Parliament (s. 28(1)). ${ }^{56}$ Such Acts will constitute primary legislation in Scotland. The law-making power is expressed (in s. 28(1)) to be subject to s. 29, which begins by stating that "[a]n Act of the Scottish Parliament is not law so far as any provision of the Act is outside the legislative competence of the Parliament" (s. 29(1)). A provision will be outside that competence in a number of circumstances specified in $\mathrm{s} .29,{ }^{57}$ including if the provision relates to reserved matters (s. 29(2)(b)) ${ }^{58}$ (reserved matters being specified in Schedule $5^{59}$ ). It is clear that any attempt by the Parliament to alter the Scotland Act outside the permitted provisions without the co-operation and legislative consent of the British Parliament, or any Scottish legislation on a reserved matter, would not produce a valid Scottish Act. ${ }^{60}$ Any such "Act" would be ultra vires the Parliament, and a judicial challenge to it must succeed. ${ }^{61} \mathrm{By}$ way of example, then, what would be the legal consequence of moves to hold a referendum on independence under the aegis of the Parliament, or even to declare Scotland to be an independent state?

There is no standing legislation of Scottish, or English, or United Kingdom extent under which referendums can be held, although there is such provision in relation to Northern Ireland ${ }^{62}$ and Wales. ${ }^{63}$ The lack of such legislation is regrettable, because fresh primary legislation is needed for each such referendum, and there is no permanent framework which would ensure that each referendum was conducted according to generally-accepted and fair procedures. ${ }^{64}$

${ }^{56}$ A Bill will become such an Act when it has been passed and has received royal assent (s. 28(2)). The validity of any Scottish Act is not to be affected by any invalidity in parliamentary proceedings leading to its enactment (s. 28(5)): but there are discrete procedures for judicial rulings on the vires of disputed laws after enactment: see ss. 98-103 and Schedule 6 .

${ }^{57}$ The Scotland Bill had proposed a prohibition on Scottish legislation which would change the Scotland Act itself, but that was deleted before enactment. Specified (and limited) provisions may be altered by the Parliament itself.

${ }^{58}$ Other circumstances are set out in s. 29(2).

${ }^{59}$ Though not as clearly as they might have been: see Brazier, "The Scotland Bill as Constitutional Legislation", pp. 18-21.

${ }^{60}$ A similar analysis applies to the Northern Ireland Act 1998: see especially s. 6 and Schedules 2, 3 .

${ }^{61}$ Ibid., s. 98 and Schedule 6.

${ }^{62}$ Northern Ireland (Entry to Negotiations, Etc.) Act 1996, s. 4.

${ }^{63}$ Government of Wales Act 1998, s. 36. This is discussed later.

${ }^{64}$ A standing Referendum Act, monitored by a permanent body, has been urged by in Constitution Unit and the Electoral Reform Society, Report on the Conduct of Referendums (1996). The Committee on Standards in Public Life has also recommended new statutory rules to ensure fairness in the conduct of referendums: see its 5th Report, The Funding of Political Parties, Cm. 4057 (1998), chapter 12. 
While the Scottish Parliament could lawfully legislate, if it wished, to hold a referendum on devolved matters, it would be unlawful as being ultra vires its powers to legislate for a referendum on independence, and any money spent on such a purpose would be spent unlawfully. For under the Scotland Act "the constitution" is a reserved matter wholly within the authority of the Parliament of the United Kingdom. ${ }^{65}$ The phrase "the constitution" is a novel one to find in a British statute: the phrase includes the Crown, the succession to the Crown, a regency and the Parliament of the United Kingdom. ${ }^{66}$ Parliamentary answers given during the passage of the Scotland Bill added little to the definition, ${ }^{67}$ but on no construction could the statutory definition of "the constitution" be deemed to exclude the status of Scotland within the United Kingdom. ${ }^{68}$ More specifically, the phrase "the Union of the Kingdoms of Scotland and England" was added at a late stage to Schedule $5,{ }^{69}$ and no referendum could be authorised on it by the Parliament. Moreover, an attempt to legislate on a matter within the exclusive jurisdiction of the United Kingdom Parliament would trespass on that Parliament itself as a reserved entity. The Scottish Parliament, of course, might persuade the British Government to legislate for such a plebiscite; the Scottish Parliament might express a view through a parliamentary resolution about the matter; the British Government might, however reluctantly, choose to enact the necessary legislation to test opinion in Scotland. Who can say whether, one day, the Parliament of the United Kingdom might agree to relinquish its authority over Scotland? But the Scottish Parliament can achieve none of those things under its own powers. A Scottish parliamentary attempt to alter the terms of the oath of allegiance would also be fatally flawed, and indeed could be self-defeating. The Scotland Act, s. 84 requires that oath to be taken by those returned as MSPs. ${ }^{70}$ As a protected provision of the Scotland Act, s. 84 could not be changed by a Scottish Act. ${ }^{71}$ It does not matter that an MSP has taken the oath on being returned on a previous occasion, or otherwise than as an MSP: ${ }^{72}$ it must be taken at a meeting of the Parliament, and an MSP can take no part in any other proceedings of the Parliament until he or she has done so. $^{73}$ If

${ }^{65}$ Section 30 and Schedule 5, para. 1.

${ }^{66}$ Ibid.

${ }^{67}$ HL Deb. vol. 585, col. WA 111 (3 February 1998).

${ }^{68}$ There is another restraint: the requirement of royal assent for Scottish Bills. Such consent could be withheld from any such measure. This is discussed later.

${ }^{69}$ Schedule 5, para. $1(b)$.

${ }^{70}$ In addition, Scottish Ministers on appointment must take the official oath prescribed by the Promissory Oaths Act 1868, as well as the oath of allegiance: Scotland Act, s. 84(4), (5).

${ }^{71}$ Ibid., s. 29(1), (2)(b), Schedule 4. Certain provisions of the Scotland Act may be amended by the Parliament: see Schedule 4, para. 4(2).

${ }^{72}$ Ibid., s. 84(1).

${ }^{73} \mathrm{Ibid}$., s. 84(2). 
the oath is not taken within two months beginning with polling day for the Scottish General Election the MSP will cease to hold his or her seat, which will be vacated by operation of law. ${ }^{74}$ In that event the recalcitrant MSPs would cease to be able to legislate, a selfdefeating result given that their purpose would be to obtain legislative changes in the 1998 settlement.

For the sake of completeness, the extreme circumstances of a unilateral declaration of independence by the Scottish Parliament may be examined very briefly. Clearly any such attempt would be nugatory in the British constitutional order. It would fail to open the triple lock of the requirement of the consent of its legislative superior, the United Kingdom Parliament, it would transgress into the reserved area of the United Kingdom constitution, and it would violate the prohibition against the Scottish Parliament itself amending protected provisions of the Scotland Act. UDI would be ineffective in English law. ${ }^{75}$ If the people and Parliament of Scotland wish to leave the United Kingdom a solution derived from negotiation and a final legislative decision of the United Kingdom Parliament would be essential to give effect to it.

Nothing in the Labour Government's policy plans for the future of Wales ${ }^{76}$ or in the Government of Wales Act 1998 itself is intended to give Wales anything that would approach the degree of autonomy that is being assumed in Scotland or (as will be seen) in Northern Ireland. This is reflected, in part, symbolically: the Welsh legislature will be an Assembly, ${ }^{77}$ not a Parliament; that Assembly will have no power to enact primary legislation; executive authority in Wales will be exercised by Secretaries rather than (as in Scotland and Northern Ireland) by Ministers $;{ }^{78}$ no symbols of nationhood are being returned to Wales-there is no equivalent of the Stone of Scone ${ }^{79}$ - and there are no Welsh counterparts to the Honours of Scotland, or to the Scottish Seal. ${ }^{80}$ This results from the early and complete union between Wales and England, and the development of Welsh civil society as an integral part of England's. There was less of a distinctly Welsh system of government and political life to carry forward into that union and therefore less to which subsequent nationalists could point for reclamation in an independent Wales. On political tests,

${ }^{74}$ Ibid., s. 84(3). An MP (like Gerry Adams or Martin McGuinness) who refuses to take the oath of allegiance may not take his or her seat, but the seat is not vacated. The United Kingdom Parliament should adopt the Scottish rule.

75 Madzimbamuto v. Lardner-Burke [1969] 1 A.C. 645.

${ }^{76}$ A Voice for Wales, Cm. 3718 (1997).

77 Its formal title is the National Assembly for Wales: Government of Wales Act, s. 1(1).

${ }^{78}$ See section III.

79 This was restored to Edinburgh Castle by the late Conservative Government.

${ }^{80}$ That is, Her Majesty's Seal appointed by the Treaty of Union to be kept and used in Scotland in place of the Great Seal of Scotland: Scotland Act, s. 2(6). 
too, the balance of opinion in Wales has remained against independence or (until 1997) even devolution, and therefore, it seems, in favour of the continued union. So, on first being offered an Assembly in $1979,{ }^{81}$ the Welsh electorate rejected it by a margin of four to one. Even today the new governmental arrangements for Wales are being put in place on the basis of a referendum result that came perilously close to rejection: $50 \cdot 3$ per cent. voted for a Welsh Assembly and 49.7 per cent. against it, on a $51 \cdot 3$ per cent. turnout. And Plaid Cymru only achieved representation at Westminster as late as 1966, when it successfully contested Carmarthen. Plaid's policy, indeed, takes account of Welsh history: it aims to achieve selfgovernment for Wales within the European Union rather than outright independence. Not surprisingly, therefore, the Labour Government's arrangements for Wales were always going to be much less ambitious than for their Scottish counterparts, with Wales remaining more closely integrated within the union and subject to a greater degree of British authority than Scotland is to be-or, indeed, than will be Northern Ireland, whose Assembly will (for example) have primary law-making powers.

The Government's White Paper on the Welsh Assembly explained the reason for setting up the Assembly in terms of correcting a "democratic deficit". ${ }^{82}$ Responsibility for many areas of life in Wales, including local government, housing, transport, health, industry, agriculture, and so on, had been assumed over time by the Welsh Office, and it had often operated in relation to many of those areas through non-accountable quangos. Over $£ 7$ billion each year are disbursed through the Welsh Office on these functions, with democratic accountability biting mainly at Westminster through the parliamentary responsibility of the Secretary of State for Wales. There has been no direct accountability to, or indeed much involvement of, the people of Wales in their governance (other than through traditional local government). In the Government's view, therefore, the main need has been to transfer as much responsibility as possible from the Secretary of State and the Welsh Office to a Welsh Assembly as a new, directly-elected body, while reserving to Westminster responsibility for functions which currently operate on a common basis throughout the United Kingdom. ${ }^{83}$

81 Under the Wales Act 1978.

${ }^{82}$ A Voice for Wales, para. 1.4.

${ }^{83}$ A Voice for Wales begins by stating (in para. 1.1) that "The Government proposes that a directly-elected Assembly will assume responsibility for policies and public services currently exercised by the Secretary of State for Wales." That may be contrasted with the first substantive sentences of Scotland's Parliament (at p. ix): "The Scottish Parliament will have law-making powers over a wide range of matters which affect Scotland. There will be a Scottish Executive headed by a First Minister which will operate in a similar way to the United Kingdom Government and will be held accountable by the Scottish Parliament." 
Quite unlike the Scottish Parliament (and, indeed, the Northern Ireland Assembly), the Welsh Assembly will have no powers to enact primary legislation. Primary law-making for Wales will continue to be done in the United Kingdom Parliament. The Assembly will have the functions that are transferred to it by or under the Government of Wales Act $1998 .{ }^{84}$ The functions will be exercised in the main under transfer of functions Orders in Council, under which powers exercisable up to now in relation to Wales by a Minister of the Crown will be transferred to the Assembly. ${ }^{85}$ Before the Assembly is first elected in 1999 a major transfer of functions order will be made. ${ }^{86}$ The essence of this process is to give the Assembly powers now and mainly enjoyed by the Secretary of State for Wales, to legislate (as he or she has been able to do) on any matter previously within the Secretary of State's powers. This delegation of authority will represent a significant transfer of democracy to Wales. The Assembly will legislate by means of Assembly subordinate legislation, as voted by the Assembly. ${ }^{87}$ The Assembly is to be bound into the Crown: the exercise by the Assembly of its functions is to be regarded as done on behalf of the Crown, ${ }^{88}$ to whom members of the Assembly ${ }^{89}$ will be required to take the oath of allegiance, and in circumstances similar to those touching their Scottish counterparts. ${ }^{90}$

Given that the clear legislative purpose of the Government of Wales Act is to endow the Welsh Assembly with the power to make secondary legislation over transferred matters, in no sense could the Assembly rival the United Kingdom Parliament. Obviously any attempt by the Assembly to legislate on matters which have not been transferred would be ultra vires, and the purported legislation would be susceptible to judicial review as provided for in the Act. ${ }^{91}$ Equally clearly, any attempt by the Assembly to enact (say) subordinate legislation to amend provisions of the Government of Wales Act would be absurd: such instruments are hierarchically inferior to statutes. Any unilateral step to alter the status of Wales would be even more flawed than any such move in Scotland. Now the Secretary of State for Wales will be empowered to alter the demarcation lines between the United Kingdom Parliament and the Welsh Assembly through a fresh transfer of functions order-and in either direction, either to enhance the Assembly's powers (the normal case) or to their

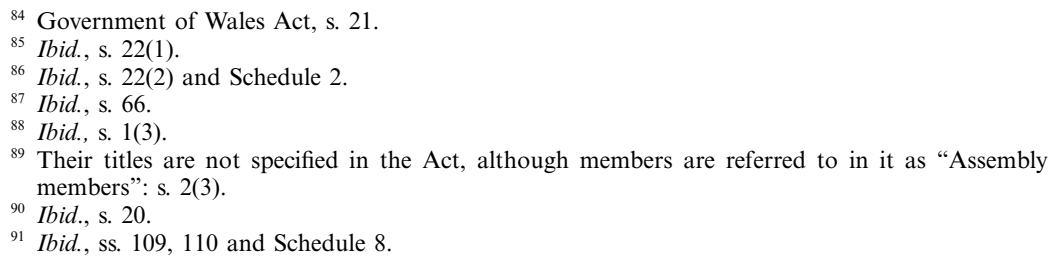


detriment (although obviously a move to take functions back to London would be resented in the absence of very convincing reasons). The United Kingdom Parliament could abolish the Assembly: as with Scotland, there is no legal entrenchment of the Government of Wales Act. ${ }^{92}$ Any move by the Assembly to hold a referendum on the status of Wales could be ultra vires for, although the Government of Wales Act will allow the Assembly to conduct polls, these will be limited to the purpose of obtaining the views of those polled about whether or how any of the Assembly's functions should be exercised. ${ }^{93}$ In short, the Welsh Assembly represents an extension to Wales of local democracy at the expense of the Government and Parliament in London, but not so as to affect the place of Wales in the United Kingdom. As with the Scottish Parliament, the Assembly will be a devolved legislature within the unitary state, and one which (unlike the Scottish Parliament or the Northern Ireland Assembly) will enjoy no primary law-making powers.

For well known historical, political and religious reasons the relationship, and therefore the union, between Great Britain and Northern Ireland has been very different from the union between the United Kingdom and the other countries and regions within it. The latest version of a constitution for Northern Ireland, enshrined in the Northern Ireland Act 1998, will come into effect on a day or days to be appointed by the Secretary of State. ${ }^{94}$ Most of that Act will be activated only if it appears to the Secretary of State that sufficient progress has been made in implementing the Good Friday agreement which was concluded in Belfast following multi-party negotiations. ${ }^{95}$ Throughout the second half of this century—again for clear historical reasons - the union of Northern Ireland with Great Britain has been underpinned by a guarantee enacted by the Parliament of the United Kingdom, first in the Ireland Act 1949, s. 1(2), ${ }^{96}$ then in the Northern Ireland Constitution Act 1973, s. $1,{ }^{97}$ and now in the Northern

${ }^{92}$ Even the argument about political entrenchment, achieved through the referendums in Scotland, Wales and Northern Ireland, is weakest in Wales given the hair's breadth nature of the vote there.

${ }_{93}$ Ibid., s. 36. It could (and no doubt will) be argued that a poll could be held to seek support for such functions being exercised by an independent Welsh Parliament. Under s. 33, the Assembly itself can make representations about any matter affecting Wales.

${ }^{94}$ Ibid., s. 101(3).

${ }^{95}$ Ibid., s. 3; Cm. 3883 (1998). Public attention has naturally centred on the commitments on decommissioning arms.

96 "Northern Ireland remains part of His Majesty's dominions and of the United Kingdom and it is hereby affirmed that in no event will Northern Ireland or any part thereof cease to be part of His Majesty's dominions and of the United Kingdom without the consent of the Parliament of Northern Ireland."

${ }_{97}$ "It is hereby declared that Northern Ireland remains part of Her Majesty's dominions and of the United Kingdom, and it is hereby affirmed that in no event will Northern Ireland or any part of it cease to be part of Her Majesty's dominions and of the United Kingdom without the consent of the majority of the people of Northern Ireland voting in a poll held for the purposes of this section in accordance with Schedule 1 to this Act." 
Ireland Act 1998, s. 1 (hereafter "the Northern Ireland Act"). ${ }^{98}$ That guarantee, ${ }^{99}$ of course, is not itself entrenched. The Parliament of the United Kingdom could therefore quite lawfully ignore such constitutional guarantees and legislate in the ordinary way to alter the status of Northern Ireland without a referendum. It is true that that Parliament might well consider itself bound as a matter of political morality to obey what is really a statement of a constitutional convention which was born in $1949 .{ }^{100}$ But as with any other convention there would be no breach of the law if its terms were broken. In any event, the terms of the guarantee have been altered under the Good Friday agreement. ${ }^{101}$ The British and Irish Governments undertook in that agreement to recognise the legitimacy of whatever choice is freely made by the majority of the people of Northern Ireland with regard to its status, whether that be to continue the union with Great Britain or to support a sovereign united Ireland. Moreover, if the people of the island of Ireland were to decide that they would prefer a united Ireland it would be a binding obligation on both Governments under the agreement to support legislation in both Parliaments to give effect to that wish. ${ }^{102}$ Quite apart from any such possible future change, the British Government undertook in the agreement ${ }^{103}$ to cause Parliament to alter the substance of s. 1 of the Northern Ireland Constitution Act 1973 by enacting what is now s. 1(2) of the Northern Ireland Act 1998, as follows.

But if the wish expressed by a majority in such a poll is that Northern Ireland should cease to be part of the United Kingdom and form part of a united Ireland, the Secretary of State shall lay before Parliament such proposals to give effect to that wish as may be agreed between Her Majesty's Government in the United Kingdom and the Government of Ireland. ${ }^{104}$

98 That section will be examined in a moment.

${ }_{99}$ Hadfield argues that the constitutional guarantee is actually in article 1 of the Act of Union, which states that ". . . the kingdoms of Great Britain and Ireland . . . shall upon [1 January 1801] and for ever after, be united in one kingdom, by the name of the United Kingdom of Great Britain and Ireland ...": Hadfield, op. cit., p. 105. The guarantee was stronger after 1949 because it was supported by political mechanisms for testing the will of the people of Northern Ireland about their future.

${ }^{100}$ Indeed, the 1973 border poll and the 1998 referendum on the Good Friday agreement constitute precedents supporting the view that the people of Northern Ireland should be consulted whenever any significant change of status is envisaged.

101 Ibid., Constitutional Issues, paras. 1, 2.

102 Ibid., para. 1(iv). See Brigid Hadfield, "The Belfast Agreement, Sovereignty and the State of the Union" [1998] P.L. 599.

${ }^{103}$ Ibid., para. 1(i) and Annex A. Obligations were also cast on the Government of Ireland, especially to seek approval for vital amendments to articles 2 and 3 of the Constitution (which it did at a referendum, in which over $90 \%$ voted in favour of deleting the Republic's historic claim to sovereignty over Northern Ireland).

${ }^{104}$ Section 1(1) of the Northern Ireland Act 1998 is the equivalent of s. 1 of the 1973 Act, but there are several changes of wording. There is no reference to Northern Ireland remaining part of "Her Majesty's dominions" (a phrase which appeared twice in the 1973 Act, s. 1); there is no reference to "any part of" Northern Ireland ceasing to be part of the United Kingdom (so that 
Furthermore, the Government of Ireland Act 1920 is to be repealed and the 1998 Act will have effect notwithstanding any other previous enactment. ${ }^{105}$ This legislation may have more importance than is indicated by the bare wording just indicated. For it will raise, as it were, a statutory doubt about the continuance of the union between Great Britain and Northern Ireland. Uniquely in the legislation which binds all parts of the country together as the United Kingdom, it is in relation to Northern Ireland that a dissolution of that union is recognised as a possibility in s. 1(2) of the Northern Ireland Act. No such query exists, in law, in relation to Scotland or to Wales. To the contrary: in the Union with Scotland Act the union is expressed to be "for ever", and in the Laws in Wales Act 1535 Wales was declared to "continue for ever . . . incorporated united and annexed to" England. ${ }^{106}$ Political reality overlays the law: the union of England and Scotland may well not last for ever: but only in the Northern Ireland Act, s. 1 does an explicit mechanism exist to test the will of the Northern Ireland people, and is a duty placed on the British Government to cede the province to Ireland if that is the wish of the people of Northern Ireland.

The New Northern Ireland Assembly was elected in consequence of the Good Friday agreement and by virtue of the Northern Ireland (Elections) Act 1998. ${ }^{107}$ That Assembly was elected for one statutory purpose: to prepare for the Assembly to assume its powers, and for the creation of the British-Irish Council and the North-South Ministerial Council. ${ }^{108}$ So far it has elected a First Minister and Deputy First Minister. The Good Friday agreement states that the Assembly will continue in shadow form until it assumes full legislative and executive authority in respect of matters currently within the remit of the six Northern Ireland Office departments, namely, agriculture, economic development, education, environment, finance, and health and social services. The Assembly will be given authority under the Northern Ireland Act to pass primary legislation within

the guarantee will refer to the entirety of Northern Ireland, presumably ruling out any partial cession), and there is other more modern phraseology. Thus the new s. 1(1) reads: "It is hereby declared that Northern Ireland in its entirety remains part of the United Kingdom and shall not cease to be so without the consent of a majority of the people of Northern Ireland voting in a poll held for the purposes of this section in accordance with Schedule 1." The substance is unaltered, but the deletion of the royalist references is a gesture towards nationalist sympathies.

${ }^{105} \mathrm{Ibid}$., s. 2: that provision mirrors the Scottish legislation, and would rule out any challenge on the ground that the Northern Ireland Act was in breach of the Act of Union with Ireland. Most of the 1973 Northern Ireland Constitution Act will be expressly repealed: Northern Ireland Act 1998, s. 100 and Schedule 15.

${ }^{106}$ That Act was repealed by the Welsh Language Act 1993, but it shows the legislative intention of the time.

${ }^{107}$ Section 1(1) provides the adjective "New" to distinguish it from previous Northern Ireland Assemblies. The word "New" will be dropped when the Northern Ireland Act 1998 is brought into force: 1998 Act, s. 4(5).

${ }^{108}$ Ibid., s. 1(1). On those two Councils, see Good Friday agreement, Strands Two and Three. 
those fields, ${ }^{109}$ subject to safeguards ${ }^{110}$ and to mechanisms, mirroring those in the Scottish Parliament, to ensure suitable co-ordination between London and Belfast and to avoid disputes between the Assembly and the United Kingdom Parliament. ${ }^{111}$ The Northern Ireland Act is identical to the Scotland Act in preserving the sovereignty of the United Kingdom Parliament, ${ }^{112}$ while transferring executive and legislative powers to the Northern Ireland Assembly. That is explicitly recognised in the Good Friday agreement. ${ }^{113}$ The new Act is entrenched in the same sense that its Scottish and Welsh counterparts are entrenched-through the wishes of the people of Northern Ireland expressed so clearly in the 1998 referendum. ${ }^{114}$

Like the Scottish Parliament, the Northern Ireland Assembly will have the power to enact primary legislation on devolved matters, but despite that power it is denied the title of "Parliament". No doubt this is in recognition of nationalist memories of the Stormont Parliament of Northern Ireland which still rankle. But the Queen is given functions in relation to the Northern Ireland Assembly. Thus, while the Assembly (like the Scottish Parliament and the Welsh Assembly) is to be elected for a fixed, four-year term ${ }^{115}$ it may be dissolved earlier in specified circumstances by the Queen, but (unlike in Scotland) under the authority of an Order in Council approved by both Houses of Parliament and by two-thirds of the members of the Assembly. ${ }^{116}$ (The Northern Ireland Bill had contained provision for the Assembly to be prorogued, ${ }^{117}$ but the clause was dropped with the Government's agreement.) As in relation to Scottish Bills, Bills passed by the Northern Ireland Assembly will require royal assent. ${ }^{118}$ Such Bills will be presented for that assent by the Secretary of State (not by the Presiding Officer ${ }^{119}$ as in the Scottish Parliament). ${ }^{120}$ The

109 Ibid., ss. 5-8 and Schedules 2-3. As with the Scottish Parliament, the Northern Ireland Assembly will have legislative competence over all matters save those that are designated excepted or reserved.

${ }^{110}$ Mainly that decisions must be arrived at on a cross-community basis in specified circumstances. Cross-community authority may be expressed through either of two voting formulas set out in the 1998 Act: see s. 4(5).

111 Good Friday agreement, Strand One, para. 26.

112 Section 5 of the Northern Ireland Act provides for the Assembly's law-making powers, but states (s. 5(6)) that "This section does not affect the power of the Parliament of the United Kingdom to make laws for Northern Ireland, ... ." That exact phrase appeared in the Northern Ireland Constitution Act 1973, s. 4(4).

113 Ibid., para. 33.

$11471 \%$ voted in favour of the Good Friday agreement, and $29 \%$ against, on an $81 \%$ turnout.

115 Northern Ireland Act, s. 31(1).

116 Ibid., s. 32.

117 This appeared originally as clause 43. It was deleted on the ground that the clause "planned for failure".

118 Ibid., s. 5(1), (2).

${ }^{119}$ On whom see ibid., s. 39. Lord Alderdice has been elected to that post. He will have a statutory duty to decide whether any Bill is ultra vires the Assembly and, if he thinks that any is, must refer it to the Secretary of State.

${ }^{120}$ Ibid., s. 14(1). 
Secretary of State will have to be satisfied that the Bill is intra vires the Assembly-and there are various judicial procedures to test that question-before a Bill could be submitted for royal assent. ${ }^{121}$ The interposition of the Secretary of State for Northern Ireland, with statutory powers and duties in relation to Assembly legislation, should preclude the prospect of the Queen being asked to assent to an ultra vires Bill, and of her receiving advice from Northern Ireland Ministers which conflicts with that offered by British Ministers (as could occur under the Scottish arrangements). ${ }^{122}$

\section{Maintaining the Union; English Devolution}

Keeping the new legislatures within their powers is a duty which will fall ultimately to the Judicial Committee of the Privy Council. Questions about the vires of any of the three legislatures to enact legislation, or of a Scottish or Northern Ireland Minister to make subordinate legislation, can be tested in the courts, with the Judicial Committee as the final arbiter. The amount of such work is impossible to predict. Informal discussions between British Government lawyers and the three executive authorities might reduce the scope for disputed legislation, but who knows? ${ }^{123}$ The future role of the Judicial Committee as a constitutional court for the United Kingdom may be a fascinating one.

Once the Northern Ireland Act joins the Scotland Act and the Government of Ireland Act by being brought into effect, the Parliament of the United Kingdom will have pushed out from London to Belfast, Edinburgh and Cardiff constitutional autonomies not seen in those capitals for 200 years and more. That is the positive - and for daily purposes the most important—effect of these measures on the constitution of the United Kingdom. As is clear, however, the United Kingdom Parliament will continue to have the legally unrestricted (though politically constrained) power to make laws for all parts of the United Kingdom, and indeed in relation to Wales that power will be exercised regularly. The devolution legislation will not change the basic constitutional position that the

${ }^{121}$ Ibid., ss. 10, 12, 79-82 and Schedule 10. The legislative competence of the Assembly depends on whether the subject-matter is "excepted" (which is outside its competence), or "reserved" or "transferred" (ibid., s. 4(1) and Schedules 2, 3). As with reserved matters in Scotland, excepted and reserved matters in Northern Ireland are listed exhaustively, so that all the rest are transferred. A reserved matter may be made into a transferred matter by Order in Council, and vice versa, provided that the Assembly approves. Excepted matters include the Crown, the United Kingdom Parliament, international relations, defence, nationality, and United Kingdom taxes; reserved matters range from such vital matters as public order and the criminal law to such things as the National Lottery. The hope is that reserved matters could be devolved to the Assembly.

${ }^{122}$ This possibility will be examined in section III.

${ }^{123}$ David Williams has objected to the use of the Judicial Committee in relation to the Welsh Assembly: Williams, "Devolution: the Welsh Perspective", pp. 48-49. 
countries and regions of the United Kingdom, while having their own legislatures and governments, ${ }^{124}$ will remain part of a unitary state. All three devolved systems will depend for their authority on their constituent Acts. None of those systems may be enlarged without the consent and legislative approval of the United Kingdom Parliament. All three main British political parties wish to maintain the unity of the United Kingdom. The new constitutional settlement will not be federal in structure. Whether a move to a federal system, or dissolution of the union, might occur by consent will be considered later. ${ }^{125}$ But in all this what of England?

Possible devolution of legislative authority to England (outside London) is a long way off. The Government's strategy is to proceed cautiously with the English dimension of constitutional reform. Ministers have rejected the notion of any form of English national assembly. ${ }^{126}$ Instead, the Government intends to see whether any region of England wishes to have an elected regional assembly. Any such preference would be expressed through a regional referendum, although no such referendum is likely during this Parliament. But a start has been made through the enactment of the Regional Development Agencies Act 1998. That is scarcely a short title to set a constitutional lawyer's pulse racing, and indeed the details of that Act are not important for present purposes. Regional development agencies (RDAs) are to be established throughout England. The members will be appointed by the Secretary of State for the Environment, Transport and the Regions, and they will seek to further (among other things) economic development, business efficiency, investment and employment in their regions. ${ }^{127}$ Agencies may have certain powers delegated to them by Ministers. ${ }^{128}$ Such a scheme is far removed from local (or regional) representative democracy: the more general constitutional significance of the Act, however, lies in the Secretary of State's power to designate within any RDA area a body to be that RDA's regional chamber. ${ }^{129}$ If the Secretary of State decides that a body is representative of people in an RDA's area, and that it has an interest in the RDA's work, he or she may direct that that body be given the title of regional chamber. The RDA must then have regard to any views expressed by the chamber, and consult it about the exercise of specified functions. The chamber will also be entitled to receive information and answers to

${ }^{124}$ On which see section III.

${ }^{125}$ See section IV.

126 The Conservative leader, however, has not. That possibility (with others) is being considered by the Conservative Party.

127 Regional Development Agencies Act 1998, ss. 1, 2, 4.

128 Ibid., s. 6.

${ }^{129}$ Ibid., ss. 8, 18. 
questions from the RDA. The road to English devolution therefore will be in the future designation of regional chambers, and then in the holding of regional referendums to transform them into elected and accountable regional assemblies. How many regional chambers will be designated, and how many referendums will be held (and with what results) must remain matters of speculation.

But London leads England, at least in the sense of having voted at a referendum in 1998 in favour of a directly-elected mayor and a twenty-five member London Assembly. ${ }^{130}$ Together they will constitute the Greater London Authority, with responsibility for economic and industrial development, strategic planning, public transport coordination, and for the emergency services. While it is clear that the Labour Government does not want the Authority to be like the former GLC, it does want the mayor to have significant executive power, and the Government would be happy for other English cities to copy the new London model.

\section{GOVERnMENTS IN THE UNITED KINGDOM}

In 1998 the United Kingdom had one body of Ministers, Her Majesty's Government in London. By 2000 there will be four groups of Ministers located in the capitals of the constituent parts of the United Kingdom.

As befits executive officers drawn from a Parliament, members of the government in Scotland ${ }^{131}$ will be known as Ministers and will be headed by a First Minister. ${ }^{132}$ The Scottish Ministers will be supported by junior Ministers and by the Lord Advocate and the Solicitor-General for Scotland. No statutory limitation will be placed on the number of Ministers who may be appointed, unlike the position in London. ${ }^{133}$ The First Minister, Scottish Ministers and the two Scottish Law Officers collectively (but excluding junior Ministers) will enjoy the title-not of a Cabinet-but of the Scottish Executive, although there is no reason why they should not be known popularly as the Scottish Cabinet. Similar nomenclature is also to be used for the Northern Ireland ministerial arrangements. ${ }^{134}$ Executive authority will be discharged on behalf of the Northern Ireland Assembly by a

${ }^{130}$ Held under the Greater London Authority (Referendum) Act 1997. See A Mayor and Assembly for London, Cm. 3897 (1998).

${ }^{131}$ For a full treatment of the Scottish Executive see Rodney Brazier, "The Scottish Government" [1998] P.L. 212.

${ }_{132}$ See generally Scotland Act, Part II, especially ss. 44-49.

${ }^{133}$ More precisely, a Prime Minister's patronage is constrained by the limit of 95 Ministers who may sit and vote in the House of Commons: House of Commons Disqualification Act 1975, s. $2(1)$.

${ }^{134}$ See generally the Good Friday agreement, Strand One, paras. 13-25; Northern Ireland Act, ss. $14-18$. 
First Minister and a Deputy First Minister, together with up to ten Ministers with departmental responsibilities and supported by junior Ministers. ${ }^{135}$ As in Scotland the Ministers collectively will not enjoy the title of the Cabinet, but will be styled prosaically the Executive Committee. ${ }^{136}$ Executive power in Northern Ireland will remain vested in the Queen, but it may be exercised by the First Minister and Deputy First Minister jointly, or by Northern Ireland Ministers as they direct. ${ }^{137}$ In Wales the Assembly will choose an Assembly First Secretary, who in turn will appoint Assembly Secretaries, the maximum number of whom will be specified in the Assembly standing orders. ${ }^{138}$ There is no provision for junior or assistant Welsh Secretaries. As in Belfast, the Welsh Assembly Secretaries will form an Executive Committee. ${ }^{139}$ The Assembly First Secretary must allocate "accountability" to members of the Executive Committee in the fields in which the Assembly has functions, although the standing orders may stipulate that one or more Secretaries will have no such allocation, thus being without portfolio. Given that the degree of devolution to Wales will not match that made to Scotland or to Northern Ireland, that less grand nomenclature is appropriate in Wales. Oddly, however, although the United Kingdom Parliament has declined to use the word Cabinet to describe any of the executives, it is the least powerful devolved executive, in Cardiff, that could formally assume that title should the Assembly so wish. ${ }^{140}$ The three executives will be responsible to their legislatures, in constitutional relationships designed to be similar to that which exists between the British Government and the United Kingdom Parliament. ${ }^{141}$ Each executive will depend on the confidence of its legislature, and if that confidence is lost the executive will have to resign or may be removed by the legislature. ${ }^{142}$

The Prime Minister is usually chosen only indirectly by the House of Commons. After a General Election the victorious party leader is appointed Prime Minister by the Queen (or remains in office if his or her party wins a further term). Thanks to the power of party, rigidly enforced by the whip system, the new House of Commons accepts the choice of the electorate, but does so only tacitly: no vote of

${ }^{135}$ Northern Ireland Act, ss. 16-19. The maximum number of Ministers can be altered with the Secretary of State's consent.

${ }^{136}$ Ibid., s. 20.

${ }^{137}$ Ibid., s. 23.

${ }_{138}$ Government of Wales Act, ss. 53-56.

${ }^{139}$ Ibid., s. 56.

${ }^{140}$ While the collective of Welsh Secretaries is to be termed the Executive Committee, the Assembly may give it a different title in its standing orders: Government of Wales Act, s. 56(2).

${ }^{141}$ Scotland's Parliament, para. 2.6; A Voice for Wales, para. 1.6; Good Friday agreement, Strand One, paras. 14, 16, 25.

${ }^{142}$ See Scotland Act, ss. 3(1)(a), 45(2), 47(3)(c); Government of Wales Act, s. 53(1), (2); Northern Ireland Act, s. 30; Good Friday agreement, Strand One, para. 25. 
confidence in the new (or continuing) Prime Minister is taken. That traditional model has been abandoned for the new devolved legislatures, largely because the systems of proportional representation through which they will be elected will normally not give one party an overall majority. ${ }^{143}$ The three electorates will therefore throw to the legislatures the task of government formation. To facilitate this, statutory rules will govern the choice of the two First Ministers and of the First Secretary. The Scottish First Minister will be appointed on the nomination of the Parliament in the form of a recommendation to the Queen, who will formally appoint him or her to office, and the person appointed will continue in office at the Queen's pleasure. ${ }^{144}$ The Assembly First Secretary will be elected, simply, by the Assembly. ${ }^{145}$ The Northern Ireland First Minister and Deputy First Minister are elected, in a necessarily more complicated way, by the Assembly: this must be done on a cross-community basis, which is designed to ensure broad support in both nationalist and unionist communities. ${ }^{146}$ In Scotland and Wales the First Minister and First Secretary will normally be the leader of the party which is able to command a simple majority in the Parliament of Assembly. These arrangements will place political and constitutional responsibility on the legislatures to make viable choices. Only in Scotland will the First Minister require formal appointment by the Queen to serve at her pleasure, but even then this should be a formality given that the Parliament's Presiding Officer is charged with making a recommendation to her on the basis of the Parliament's own nomination. Royal appointment signifies the dignity and importance of the officer at the head of the Scottish Executive.

It is possible that government formation in Edinburgh may provide guidance for that process in London. If the parties represented in the Scottish Parliament should find it difficult on any occasion to reach agreement on a nominee for First Minister, the Parliament's Presiding Officer may have to negotiate an agreement. Statutory responsibility is on the Parliament itself to make a nomination; if it fails to do so within a prescribed time limit the

${ }^{143}$ The Scottish Parliament and the Welsh Assembly will be elected by the additional member system, and the Northern Ireland Assembly by the single transferable vote. PR is spreading throughout the United Kingdom: the Government wants future European Parliament elections to be conducted using the regional list system; it is possible that elections to the Commons itself may be conducted by a more proportional system if that is approved at a national referendum following the Report of the (Jenkins) Independent Commission on the Voting System, Cm. 4090 (1998).

144 Scotland Act, s. 45(1), 46.

${ }_{145}$ Government of Wales Act, s. 53(1).

${ }_{146}$ Northern Ireland Act, s. 16; Good Friday agreement, Strand One, para. 15. David Trimble and Seamus Mallon were so elected. On cross-community voting, see above note 110 . 
Presiding Officer must propose a dissolution. ${ }^{147}$ Before that time expired, however, the Presiding Officer would need to negotiate, and how that was done could have repercussions for the United Kingdom: if a more proportional voting system were to be introduced for elections to the House of Commons, resulting in hung Parliaments at Westminster, any relevant Scottish experience might provide a model from which lessons for that Parliament might be drawn. Perhaps the parties themselves will reach agreement without outside help; perhaps the Presiding Officer, if called upon to arbitrate, would do so ad hoc on each occasion; or perhaps he or she will develop guidelines-conventions-to be followed in such cases.

In forming a government a wide discretion is given to the Scottish First Minister and the Assembly First Secretary. The First Minister may appoint as many Ministers and junior Ministers as he or she judges appropriate, subject to the approval of the Parliament and of the Queen for the individuals selected. ${ }^{148}$ The Welsh First Secretary's power to appoint Assembly Secretaries may be subject to a maximum number agreed in Assembly standing orders, but neither individually nor collectively do they have to receive any endorsement from the Assembly. ${ }^{149}$ Neither the legislation for Scotland nor for Wales makes mention of the party allegiances of Ministers or Secretaries: the choice of individuals will depend on the political realities and personalities in the Parliament and the Assembly. If one-party executives can be formed, well and good (although minority or coalition administrations are more likely). But in Northern Ireland statutory rules will prescribe how Ministers are to achieve office, ${ }^{150}$ because coalition will be the permanent and prescribed condition. The number of Ministers will be determined jointly by the First Minister and the Deputy First Minister, subject to a maximum of ten; they will also jointly allocate portfolios. Posts will be allocated to the political parties on the basis of the number of seats each party has in the Assembly. ${ }^{151}$ This is clearly vital in Northern Ireland to ensure that the parties, returned by STV, have proportional representation on the Executive Committee. The choice of each individual is for the party concerned, and it may decline to nominate a person and (more to the point) may change its nominee. This all gives the Northern Ireland political parties powers to the detriment

${ }^{147}$ Scotland Act, ss. 3, 46. The Queen then has a discretion to dissolve the Parliament: Scotland Act, s. 3(1)(b), 3(2); Brazier, "The Scottish Government", pp. 216-217.

${ }^{148}$ Scotland Act, ss. 47-49. The Queen may have the same conventional role as she does in relation to the appointment of her Ministers in London-to offer comments and even objections to particular names, but falling in with the head of government's wishes in the end. For this process see Rodney Brazier, Constitutional Practice (2nd ed., 1998), pp. 63-65.

${ }^{149}$ Government of Wales Act, s. 53.

${ }^{150}$ Northern Ireland Act, s. 18.

${ }^{151}$ Northern Ireland Act, ss. 18(2)-(12); Good Friday agreement, Strand One, paras. 16, 21, 22, 25. 
of the First Minister-a very different method than that which obtains in the other devolved legislatures, or indeed at Westminster. The Assembly may remove a Minister from office by a crosscommunity vote ${ }^{152}$ a Minister may resign at any time to the First Minister and Deputy First Minister jointly. ${ }^{153}$ Members of the three executives will all be required to take oaths (or to make affirmations). All Scottish Ministers must take the oath of allegiance and (except for junior Ministers) the official oath. ${ }^{154}$ Assembly Secretaries will take the oath of allegiance as members of the Assembly, but no official oath. ${ }^{155}$ All Northern Ireland Ministers, as a condition of appointment, must affirm the pledge of office, which is quite elaborate, incorporating a Ministerial Code of Conduct (though not surprisingly containing no reference to allegiance to the Queen). ${ }^{156}$ The pledge includes an obligation, novel in the United Kingdom governmental system, to be bound by the doctrine of collective ministerial responsibility: Ministers will undertake to support and to act in accordance with all decisions of the Executive Committee and Assembly.

The Queen is at the apex of British government. She is a symbol of national identity and national unity, and that symbolism will be the more important in the devolved constitutional system. The Government intends that her position will enhance the continuing unity of Great Britain ${ }^{157}$ when the devolved systems are in place. In the Scottish devolution White Paper the Government noted that Scotland would ("of course") remain an integral part of the United Kingdom, and that the Queen would continue to be head of state. ${ }^{158}$ The Queen will have constitutional duties in relation to the Scottish Parliament, such as formally dissolving it in certain circumstances; ${ }^{159}$ she will formally appoint the First Minister, ${ }^{160}$ and approve the appointment of Scottish Ministers and junior Ministers. That they will hold office at her pleasure mirrors the British constitutional position. ${ }^{161}$ The requirement that Scottish Ministers and Welsh Secretaries must take the oath of allegiance is another way in which

${ }^{152}$ Northern Ireland Act, s. 30. If the Assembly so votes, that person will be excluded from office for 12 months: s. 30(1). There is also a provision to exclude an entire political party from ministerial office for 12 months: s. 30(2).

153 Ibid., s. $18(9)(a)$.

154 Scotland Act, s. 84(4), (5).

155 Government of Wales Act, s. 20.

${ }_{156}$ Northern Ireland Act, ss. 18(8), 19(3) and Schedule 4; Good Friday agreement, Strand One, para. 23 and Annex A.

${ }_{157}$ This point has not been advanced with respect to Northern Ireland.

158 Scotland's Government, para. 4.2.

159 Scotland Act, s. 2(5), 3(2).

${ }^{160}$ The First Minister will also be Keeper of the Scottish Seal (ibid., s. 45(7)) - perhaps as a symbol of office from the Queen.

${ }^{161}$ It will also facilitate reshuffles, because any Minister who declined to leave office could be dismissed. 
the union will be underpinned. ${ }^{162}$ Perhaps the Scottish First Minister will also be made a Privy Counsellor. Royal assent for Scottish Bills, too, underlines the formal constitutional position that the Parliament will legislate for Scotland as part of the United Kingdom of which the Queen is head of state. It remains to be seen to what extent the relationship between the First Minister and the Queen will copy that between her and the Prime Minister, involving the Queen's conventional rights to advise, to encourage and to warn. But including the Queen in the Scottish system may also involve risks. True, the Queen's British duty of finding a head of government (which is not usually difficult) has been transferred in Scotland to the Parliament and the Presiding Officer; but by giving the First Minister direct access to the Queen the possibility could arise of conflicting advice reaching her from Edinburgh and London. That could happen over the terms in which the Queen were to open the Scottish Parliament ${ }^{163}$ or in a much more worrying form if the British Cabinet were ever moved to recommend that royal assent be not given to a Scottish Bill which, while within the powers of the Parliament, was inimical to British national interests or policy. ${ }^{164}$ In the nature of things no such risk could arise in Wales, or in Northern Ireland. The Welsh Assembly will be a Crown body, which (for example) the Queen would formally open after each election. ${ }^{165}$ Royal assent to Northern Ireland Bills will require the intervention of the Secretary of State, and if the British Government were ever minded to block a Northern Ireland Bill it would be the Secretary of State who would tender ministerial advice that royal assent be not granted, thus keeping the Queen at one remove from the constitutional row that would then erupt.

British central government must be affected by the ministerial authority which is to be lost to the three parts of the United Kingdom. It would be logical if the size of that government were to be reduced. In general terms the responsibilities of British Ministers will obviously be cut as a result of the devolution of legislative and executive power. In terms of personnel, it might be thought that question marks could exist against the continuance of the offices of three Secretaries of State for the three countries and regions, many of whose duties will be assumed by the devolved authorities. But the British Government has been keen to stress that although the duties

${ }^{162}$ See also Notes on Clauses (Scottish Office, January 1998), cl. 79.

${ }^{163}$ Although this could be avoided by a "Queen's Speech" which (unlike the Westminster version) made no reference to Scottish Executive policies (which could be at variance with those of British Ministers).

${ }^{164}$ The Cabinet might avoid royal embarrassment by passing legislation at Westminster to negative the offending Scottish Act. See generally Brazier, "The Scottish Government", p. 220.

${ }^{165}$ See Government of Wales Act, s. 1(3); A Voice for Wales, para. 1.20. 
of those offices will change, they will remain. Thus all three Secretaries of State will continue to represent the interests of Scotland, Wales and Northern Ireland in the Cabinet especially in relation to reserved areas, and they will argue for resources; they will have duties in relation to the devolved legislatures. ${ }^{166}$ It should, however, follow that the number of junior Ministers in the three territorial Offices should be reduced, because many of their particular responsibilities will be carried out by the new Ministers or Secretaries. It will be the case that the Lord Advocate and the Solicitor-General for Scotland will leave the British Government to join the Scottish Executive, ${ }^{167}$ but the need for legal advice in London about Scotland will be met by the appointment of a new member of the Government, the Advocate General for Scotland, who will be the Scottish Law Officer to the United Kingdom. ${ }^{168}$

\section{The Future of the United Kingdom}

I want to leave aside the constitutional legislation which is altering the structure of government in the United Kingdom, and to look further ahead. Does the future of the United Kingdom as a constitutional entity lie in continued union, or in dissolution, or in federation?

In the long history of the British Islands the United Kingdom has existed for barely two hundred years. ${ }^{169}$ Current tensions make the continued existence of the United Kingdom as a constitutional entity uncertain. It is, of course, the consent of the Parliament of the United Kingdom which would be needed for any further alterations to the status of the constituent parts of the United Kingdom. Any foreseeable United Kingdom Parliament, however, is likely to contain a unionist majority. The maintenance of the union between England, Wales, Scotland and Northern Ireland (subject in the latter case to any contrary expression of the people's wish) is the firm policy of the Labour Party and (even more emphatically) of the Conservative and Unionist Party. That stance no doubt reflects the preference for the union which exists in England and elsewhere, possibly shored up by the forces of inertia, by a view that the United Kingdom has come through much together, and by the belief that the larger unit is a

166 Scotland's Parliament, para. 4.12; A Voice for Wales, paras. 3.33-3.35. The Secretary of State for Northern Ireland will have many duties under the Northern Ireland Act, including those in relation to activating the Act itself, enactment of Northern Ireland Bills, possible exclusion of Ministers from office, elections, obtaining the block grant which will finance the Assembly, and so on. That Secretary of State will be required for the foreseeable future.

${ }_{167}$ Scotland Act, s. 44(1), 48(6). They need not be MSPs: ibid., s. 27.

168 Ibid., ss. 32(4), 87; Scotland's Parliament, para. 4.9.

${ }^{169}$ On the formation of British national identity over a rather longer period see Colley, op. cit. 
bigger player in the world than would be any of the individual parts alone. It seems unlikely that either party would do other than argue passionately for the constitutional benefits which they say the union brings to the countries, nations and regions of the collective whole, and will resist separatist movements. ${ }^{170}$ Both parties are now committed to the terms of the Scotland Act (at least, more or less in the Conservatives' case). The force of unionism between England and Wales is stronger. The Government's commitment to the Welsh Assembly as the furthest that devolution will go in the principality is clear; Conservative support appears lukewarm at best even for that modest settlement; and the Assembly itself is based on the least certain expression of popular desire for greater autonomy anywhere in the United Kingdom. Who with confidence could assert that the Welsh Assembly will be a permanent feature in the United Kingdom constitution? Is it not at least possible that it might be abolished if, in the light of experience, it failed to function in a manner satisfactory to Wales and the United Kingdom? Any such collapse would strengthen, not undermine, the union between Wales, England and the United Kingdom.

Yet—of course - there are stresses which pull against union. The consistent policy of the SNP has been to strive for an independent Scotland, using whatever legitimate means come to hand. The party worked hard at the 1997 referendum for Scottish approval for a Parliament with tax-varying powers as a sort of down payment on independence-the very process about which the Conservative Party has warned so consistently in recent years. ${ }^{171}$ In recent opinion polls the SNP has been favourite to be the largest party in the Parliament, and it intends to seek a referendum on independence in the first parliamentary term. While the constitutional and legal mechanisms are patently in place to continue the supremacy of the United Kingdom Parliament over Scotland's future, if the view takes hold in Scotland (perhaps expressed unambiguously through a referendum if one were permitted by the United Kingdom Parliament, or demanded by a majority of MSPs), would it be a credible or viable policy for the unionist parties at Westminster to resist such demands, presumably by all means not excluding the use of force? A bold step which the Government might consider would be to extend the new form of the Northern Ireland unionist guarantee to Scotland. It might be better for the Government to seize the initiative, to guarantee the continued union for so long as the people of Scotland wanted it, but to agree

${ }^{170}$ In Labour's case there is also a low political reason for union: the party does very well at parliamentary elections in Scotland.

171 John Major made the maintenance of the Union a key part of his 1992 General Election campaign. 
to respect any expression of a wish for independence. The advantages for the British Government of such a step would be that it could set the terms in which any such expression might be deemed to be valid (perhaps including a threshold which had to be achieved, and perhaps with minimum periods to elapse between referendums), and it would be seen to grant (in the possibility of a referendum) the very thing which it would otherwise merely determinedly resist despite nationalist demands in Scotland.

In Northern Ireland all the political parties are committed to abiding by the wishes of the majority as to union with Great Britain or with a united Ireland. At the last expression of opinion on the border issue in 1973 nearly 600,000 people voted for Northern Ireland to remain in the United Kingdom, while only some 6,500 voted for union with the Republic_-but in a poll in which the Social Democratic and Labour Party (SDLP) and 41 per cent of the population abstained. ${ }^{172}$ A border poll may now be ordered by the Secretary of State if it appears likely that a majority would vote for union with Ireland, but any such polls must be seven years apart. ${ }^{173}$ That there is a significant nationalist population in Northern Ireland can be seen, for example, by the fact that the SDLP beat the Ulster Unionist Party in percentages of votes obtained at the 1998 elections to the Northern Ireland Assembly (22 per cent. to $21 \cdot 3$ per cent.), and by Sinn Fein's poll of $17 \cdot 3$ per cent of the vote. Looking ahead, therefore, while it is possible that the 1998 settlement and institutions will endure, it is equally plausible that, one day, the people of Northern Ireland might opt to join the Republic of Ireland, as provided for in the guarantee. The absolute certainties of permanent union which existed from 1922 until the abolition of the Stormont Parliament in 1973 seem very remote today. (It must be added, in the light of history, that an equally plausible outcome might be the collapse of the 1998 settlement.)

But even if the Labour Government's new constitutional settlement—which will be completed when the Scottish Parliament and the Welsh Assembly have been elected in the spring of 1999, and when the Secretary of State for Northern Ireland moves the Northern Ireland Assembly from shadow into substance-does endure, there would remain a case for taking matters one step further, towards formal federalism.

It is notorious that the word "federal" can be made to mean what the user wants it to mean: the word has no fixed, legal meaning. ${ }^{174} \mathrm{It}$

${ }^{172}$ No further poll has been held. The Northern Ireland Constitution Act 1973 permitted such polls at 10 -year intervals.

173 Northern Ireland Act, s. 1 and Schedule 1.

${ }^{174}$ For a good short account see Eric Barendt, An Introduction to Constitutional Law (1998), 
is that elasticity that has allowed friction to enter the debates about the development of the European Union. The concept can embrace a strong central executive and legislature, with subordinate local units enjoying only specified authority but who none the less have constitutional protections against the centre (as, say, in Canada); or it may imply strong local units with a limited central government (as in the United States). And between those two extremes there are various other balances which can be struck in a federal system. There are, too, various reasons why a federal constitution may be created. Local units will wish to retain certain rights. There will be perceived advantages in taking action collectively in certain matters within a federation (invariably including defence, external relations, and so on), while establishing rules to keep the federal authorities within those collective purposes. Sometimes there may be an initial distrust of strong central government, as was the case with the American colonists, and in postwar Germany. Occasionally that concern may be reflected in a federal constitution which ensures that local rights cannot be taken away, even by constitutional amendment. Despite those variable factors, a federal constitution will contain three principal features, namely, (i) the delimitation of federal and local powers, (ii) the protection of that delimitation by making constitutional amendment difficult (requiring more than a bare parliamentary majority in the federal legislature) - usually this will include the consent of the local legislatures or populations-and (iii) the policing of the delimitations by a supreme constitutional court.

The case for moving towards a federal constitution for the United Kingdom, in brief, may be expressed this way. By 2000 significant powers will exist in the countries and regions of the United Kingdom (although not in England): the old, centralised British state will have passed away: it follows that the next step to a federal constitution would be a much smaller one to take than would have been the case as recently as (say) in 1995. It may be that a de facto federal constitution will be in place, if the United Kingdom Parliament and Government leave the devolved authorities in peace-as the Northern Ireland Parliament was for fifty years. Assuming that sufficient time has been allowed to elapse to see that the 1998 settlement will endure, a clear division of responsibilities between London and the other capitals may emerge. This would be a practical expression of subsidiarity within the United Kingdom. A new federal constitution would ensure that the devolved systems would be protected from 
easy infringement by the Parliament of the United Kingdom: never again could a Government, relying on its parliamentary majority, abolish tiers of local government contrary to their wishes. A final advantage would be that representatives of the various parts of the kingdom could meet and collectively decide the settlement: this did not happen in 1998. Federal constitutions usually spring from a truly national constitutional assembly or process.

What, then, might be the prospects for the adoption of such a federal solution for the United Kingdom? Strangely, perhaps, it might be those who champion local rights the most strongly who would oppose a federal structure for the United Kingdom the most vigorously. Nationalists in Scotland want independence, not the freezing of Scotland within a permanent federation. Nationalists in Northern Ireland, too, would be loath to enter a federation, because they see the destiny of Northern Ireland in a unified Ireland. An obvious compromise might be to include a mechanism for local resignation from the federation. The federal constitution would operate with its advantages until any component part succeeded in activating the dissolution mechanism. British antipathy towards constitutional theory, preferring that institutions be allowed to develop pragmatically, ${ }^{175}$ would also hinder the adoption of a federal constitution. ${ }^{176}$ The 1998 devolution settlement, which provides for separate and different development in Scotland, Wales and Northern Ireland, fits better with that approach. ${ }^{177}$ In any event, there is a case for establishing a review mechanism to examine how successfully the devolution legislation has worked. ${ }^{178}$

\section{Final Thoughts}

On the basis of the referendum results in Scotland, Wales and Northern Ireland the immediate aspirations of the people there will be met through the new democratic assemblies and governments that are being established. Very many matters of daily importance to citizens, such as housing, education and health, will become the responsibility of those new and accessible authorities. In arriving at that new disposition a revised United Kingdom constitution-neither federal, nor as purely unitary as it was-has been developed. It will produce a politically weaker central government. Edinburgh, Cardiff

75 David Simpson, Romanticism, Nationalism and the Revolution Against Theory (1993).

176 That attitude may also explain in part the Labour Government's disinclination to present its constitutional reform programme as a related whole, driven by any constitutional theory.

${ }^{177}$ This was a reason why the Royal Commission on the Constitution supported a devolutionary approach: op. cit., para. 520.

${ }^{178}$ See Williams, "Devolution: The Welsh Perspective", p. 49; Brazier, Constitutional Reform, chapter 2 . 
and Belfast will have gained substantial legislative and executive authority at the expense of the United Kingdom Parliament and the British Government. Because those powers will be underpinned by the popular sovereignty expressed through the referendums, it would be difficult (albeit legally possible) for the United Kingdom Parliament to take back those powers without a similar expression of popular sovereignty. While the Scottish constitution has been limited in law by the Westminster Parliament, that constitution will provide a new and continuing means for Scots, if they wish, to express their national aspirations. Assuming that the new Northern Ireland constitution is activated, Northern Ireland will be moved nearer to the joint suzerainty of the United Kingdom and the Republic of Ireland, and a mechanism now exists in law which would require the cession of Northern Ireland to the Republic if the majority in the North so wish.

For the moment constitutional power is to be redistributed within the United Kingdom. It is quite possible, however, that in the first few decades of the new century the state known as the United Kingdom may disappear, to leave Scotland independent once more, a whole island of Ireland, and-after a three hundred year diversion-England and Wales alone. 